\title{
DZIAŁANIA WIZUALIZACYJNE WYBRANYCH ZAKŁADÓW LECZNICZYCH JAKO PRZEJAW MOŻLIWOŚCI PROMOCJI W SEKTORZE OPIEKI ZDROWOTNEJ
}

\author{
Agata Krukowska-Miler \\ Politechnika Częstochowska \\ Wydział Zarządzania
}

\begin{abstract}
Streszczenie: W niniejszym artykule przedstawiono główne założenia promocji w odniesieniu do zakładów leczniczych. Nacisk położony jest na stronę wizualizacyjną promocji. Zaprezentowano możliwości i ograniczenia w tym zakresie oraz akty prawne i dobre praktyki, które regulują możliwości promocji, a w szczególności reklamy zakładów leczniczych. Artykuł koncentruje się głównie na elementach dotyczących informacji zewnętrznej znajdującej się na zakładach leczniczych, wskazując na dobre rozwiązania, jak i na braki w tym względzie. Drugi aspekt dotyczy tworzonych stron internetowych $\mathrm{i}$ ich wpływu na lepsze rozpoznawanie określonego zakładu. Celem artykułu jest krytyczne przyjrzenie się wyzwaniom, jakie stoją przed zarządzającymi marketingiem w zakładach leczniczych, i możliwościom promocji wizualizacyjnej tychże. Artykuł jest oparty na przeprowadzonych badaniach własnych, dotyczących zarówno obserwacji rozwiązań poszczególnych zakładów leczniczych, jak i na wywiadzie bezpośrednim z pacjentami i potencjalnymi pacjentami określonych zakładów. Badanie dotyczy rozpoznawalności stron internetowych konkretnych zakładów. Artykuł może stać się podpowiedzią dla zarządzających zakładami leczniczymi, w jaki sposób wykorzystać omawiane narzędzia do lepszego zarządzania placówką, na co należy zwrócić uwagę, jakie są ograniczenia, gdzie szukać rozwiązań, jakich błędów i niedoskonałości unikać, a w szczególności jak te działania postrzegają klienci zakładów leczniczych, czyli pacjenci.
\end{abstract}

Słowa kluczowe: promocja, zakład leczniczy, wizualizacja, ograniczenia, wyzwania, strony internetowe

DOI: 10.17512/znpcz.2016.2.06

\section{Możliwości promocji zakładów leczniczych w Polsce}

Ostatnie lata przynoszą coraz więcej zmian w sektorze opieki zdrowotnej. Znaczące przeobrażenia zaczęły zachodzić $\mathrm{w}$ latach dziewięćdziesiątych XX wieku i trwają do dziś. Po zmianie ustrojowej oraz po uchwaleniu w 1991 r. ustawy o zakładach opieki zdrowotnej (por. Dercz, Rek 2007, ss. 14-64; Ustawa z dnia 15 kwietnia 2011 r. o działalności leczniczej; http://www.zdrowie.abc.com.pl/czytaj//artykul/nowe-definicje-i-podmioty-przewodnik-po-ustawie-z-dnia-15-kwietnia2011-r-o-dzialalnosci-leczniczej) zaczęto w większym stopniu zwaracać uwagę na potrzebę konkurencyjności zakładów leczniczych. Ustawa ta dawała podstawy do wprowadzenia radykalnych zmian finansowania i organizacji instytucji zdrowotnych. Ustawa o zakładach opieki zdrowotnej dopuszczała istnienie różnych struktur 
organizacyjnych i własnościowych w systemie. Ten akt prawny dopuścił istnienie niepublicznych zakładów opieki zdrowotnej (Ustawa z dnia 30 sierpnia $1991 \mathrm{r}$. o zakładach opieki zdrowotnej, art. 8 ust. 3). „Niepublicznym zakładem opieki zdrowotnej jest zakład opieki zdrowotnej utworzony przez instytucje i osoby, o których mowa w ust. 1 pkt 4-8, z zastrzeżeniem ust. 2 pkt 2 , tj.:

Wszystkie niepubliczne zakłady opieki zdrowotnej podlegają wpisowi do rejestru zakładów opieki zdrowotnej prowadzonego przez wojewodę według miejsca siedziby zakładu" (Ustawa z dnia 30 sierpnia 1991 r. o zakładach opieki zdrowotnej, art. 8 ust. 3).

W 2011 roku nastąpiła zmiana. Została uchwalona ustawa o działalności leczniczej. $\mathrm{Z}$ uwagi na zakres podejmowanych spraw nowa ustawa przypomina $\mathrm{w}$ dużym stopniu ustawę z dnia 30 sierpnia 1991 r. o zakładach opieki zdrowotnej (tekst jedn.: Dz.U. 2007 nr 14 poz. 89, z późn. zm.) - dalej u.z.o.z. - którą zastępuje. Ustawa o działalności leczniczej kształtuje normatywnie rynek świadczeniodawców medycznych w Polsce, zmieniając częściowo obecny stan prawny i faktyczny. Zgodnie z obowiązującym poprzednio prawem (a szczególnie ustawą o zakładach opieki zdrowotnej) świadczenia zdrowotne w Polsce mogły być udzielane zasadniczo tylko przez niżej wskazane podmioty:

- zakłady opieki zdrowotnej (publiczne i niepubliczne);

- indywidualne praktyki medyczne (lekarskie, pielęgniarskie, położnych);

- grupowe praktyki medyczne (lekarskie, pielęgniarskie, położnych), w formie spółki cywilnej lub partnerskiej.

Obecnie ustawa o działalności leczniczej stanowi fundamentalną podstawę prawną funkcjonowania wszystkich, tj. zarówno kompleksowych (przedsiębiorcy, zakłady opieki zdrowotnej), jak i indywidualnych (prywatne praktyki), podmiotów udzielających świadczeń zdrowotnych, tj. wykonujących według nowej nomenklatury działalność leczniczą, i wprowadza nowy podział świadczeniodawców (http://www.zdrowie.abc.com.pl/czytaj/-/artykul/nowe-definicje-i-podmiotyprzewodnik-po-ustawie-z-dnia-15-kwietnia-2011-r-o-dzialalnosci-leczniczej).

$\mathrm{Na}$ podstawie tych ustaw opiera się głównie działalność podmiotów leczniczych. Coraz większa konkurencyjność rynku wymaga dostosowania się do zmieniającego się otoczenia oraz informowania o tych zmianach. Jeśli chodzi o informowanie, często na myśl przychodzi proces promocji. W skład instrumentów promocji-mix wchodzą: reklama, public relations, promocja sprzedaży, sprzedaż osobista, marketing bezpośredni. Promowanie usług zdrowotnych często rozumiane jest jako promowanie samego zakładu leczniczego oraz tworzenie jego wizerunku. Szczególnym przypadkiem promocji usług zdrowotnych i zakładów leczniczych jest reklama, która de facto jest zabroniona.

Przepisy obowiązującej od 1 lipca 2011 r. ustawy z dnia 15 kwietnia 2011 r. o działalności leczniczej (Dz.U. $2011 \mathrm{nr} 112$ poz. 654) utrzymały zakaz reklamy świadczeń zdrowotnych, który obowiązywał na podstawie uchylonej ustawy z dnia 30 sierpnia 1991 r. o zakładach opieki zdrowotnej (Dz.U. $2007 \mathrm{nr} 14$ poz. 89, z późń. zm.), a także uchylonego art. 56 ustawy z dnia 5 grudnia 1996 r. o zawodach lekarza i lekarza dentysty (Dz.U. $2008 \mathrm{nr} 136$ poz. 857, z późń. zm.). Na podstawie tego przepisu Naczelna Rada Lekarska w podjętej uchwale ustanowiła 
szczegółowe zasady podawania do publicznej wiadomości informacji o udzielaniu przez lekarzy świadczeń zdrowotnych w ramach indywidualnej praktyki lekarskiej. Obecna regulacja umożliwia podmiotom wykonującym działalność leczniczą na podawanie do wiadomości publicznej informacji o zakresie i rodzajach udzielanych świadczeń zdrowotnych, jednakże treść, jak i forma tych informacji nie może mieć cech reklamy (http://www.prawoimedycyna.pl/?str=artykul\&id=1023).

Problemem może być ustalenie, co jest informacją, a co reklamą. Podaje się, że w tym przypadku jako reklamę można traktować próby nakłonienia pacjenta - konsumenta do skorzystania $\mathrm{z}$ tych świadczeń poprzez informowanie o promocjach, zniżkach, wszelkiego rodzaju rabatach czy też programach lojalnościowych, a także informowanie, iż z usług danego podmiotu skorzystały inne osoby, w szczególności znane szerokiej opinii publicznej. Niewątpliwie sytuacja taka będzie miała miejsce wówczas, gdy informacje będą zawierały również zachętę do skorzystania ze świadczeń zdrowotnych z uwagi na nadzwyczajną skuteczność leczenia przez określony podmiot czy też z uwagi na zastosowaną metodę lub urządzenia medyczne. (Gubiński 1993, s. 136, za: http://www.prawoimedycyna.pl/?str=artykul\&id=1023). Informacja ta musi być też dostępna publicznie poprzez odpowiednie kanały informacyjne.

Ze względu na nową ustawę o zakładach leczniczych zakazem reklamy objęta jest także promocja zdrowia (Ustawa z dnia 15 kwietnia 2011 r. o działalności leczniczej, art. 2 ust. 1 pkt 7). Może to stwarzać pewne problemy z dotarciem do adresatów. Także granica między informowaniem a reklamą w niektórych przypadkach jest nieostra.

Za naruszenie zakazu reklamy świadczeń zdrowotnych lekarz ponosi również odpowiedzialność zawodową (Ustawa z dnia 2 grudnia 2009 r. o izbach lekarskich), ponieważ naruszenie przepisów związanych $\mathrm{z}$ wykonywaniem zawodu lekarza, jak i zasad etyki lekarskiej stanowi przewinienie zawodowe. Kodeks Etyki Lekarskiej wyraźnie zabrania lekarzom wszelkiego reklamowania się oraz zakazuje im: wyrażania zgody na używanie swego nazwiska i wizerunku dla celów komercyjnych, narzucania swych usług chorym, pozyskiwania pacjentów w sposób niezgodny z zasadami deontologii i etyki lekarskiej oraz lojalności wobec kolegów, a także stosowania metod nieuczciwej konkurencji, szczególnie w zakresie nierzetelnego informowania o swoich możliwościach działania, jak i kosztach leczenia (Kodeks Etyki Lekarskiej, art. 63, 65 i 66). Możliwe jest podanie do informacji publicznej przez lekarza stopnia lub tytułu naukowego, stopnia specjalizacji i określenie udzielanych świadczeń, ale to jedynie za zgodą właściwej Rady Lekarskiej (Czerw (red.) 2010, s. 54).

Przepisy ustawy o radiofonii i telewizji zakazują nadawania przekazu handlowego świadczeń zdrowotnych w rozumieniu przepisów o działalności leczniczej udzielanych wyłącznie na podstawie skierowania lekarza (Ustawa z dnia 29 grudnia $1992 \mathrm{r}$. o radiofonii i telewizji, za: http://www.prawoimedycyna.pl/?str=artykul\&id=1023). Zakaz reklamy dotyczy także produktów leczniczych potocznie nazywanych ,przepisywanymi na receptę", a regulowane jest to ustawą z dnia 6 września 2001 r. - Prawo farmaceutyczne (Dz.U. 2004 nr 53 poz. 533, z późn. zm.) (Janiszewska i in., 2009, s. 353).

Również użycie banerów czy też tablic informujących o działalności leczniczej są dokładnie określone w odpowiednich ustawach oraz rozporządzeniach. 
Obowiązek upowszechnienia informacji o zakresie świadczeń, jakie są udzielane w konkretnym zakładzie opieki zdrowotnej, wynika z ustawy z dnia 6 listopada 2008 r. o prawach pacjenta i Rzeczniku Praw Pacjenta (Dz.U. 2009 nr 52 poz. 417, z późn. zm.). Podmiot udzielający świadczeń zdrowotnych (np. zakład opieki zdrowotnej) powinien udostępnić informację o rodzaju i zakresie udzielanych świadczeń w formie pisemnej poprzez umieszczenie jej w swoim lokalu, w miejscu ogólnodostępnym (np. wywieszając ją na ścianie w holu głównym przychodni lub w izbie przyjęć szpitala). Za dopuszczalne należy uznać umieszczenie omawianej informacji w kilku miejscach tego samego budynku, a także nawet na zewnątrz budynku (na ścianie) (http://www.zdrowie.abc.com.pl/czytaj/-/artykul/zakresobowiazku-podawania-okreslonych-informacji-do-wiadomosci-pacjentow-przezswiadczeniodawcow).

Szczegółowe założenia przedstawione są w uchwale nr 18/98/III Naczelnej Rady Lekarskiej oraz muszą być zgodne z ustaleniami Okręgowych Izb Lekarskich (Bukowska-Piestrzyńska 2007, s. 89).

W przypadku zakładów opieki zdrowotnej mających kontrakt z NFZ istnieje obowiązek informacyjny związany $\mathrm{z}$ udzielanymi świadczeniami, wynikający z Rozporządzenia Ministra Zdrowia z dnia 6 maja 2008 r. w sprawie ogólnych warunków umów o udzielanie świadczeń opieki zdrowotnej; świadczeniodawca jest zobowiązany do podania do wiadomości świadczeniobiorców informacji o godzinach i miejscach udzielania świadczeń w poszczególnych zakresach świadczeń. Świadczeniodawca ma także obowiązek umieszczenia na zewnątrz budynku, w którym udzielane są świadczenia, w miejscu ogólnie dostępnym, tablicy ze znakiem graficznym Funduszu według wzoru określonego przez prezesa Funduszu (Rozporządzenie Ministra Zdrowia z dnia 6 maja 2008 r. w sprawie ogólnych warunków umów o udzielanie świadczeń opieki zdrowotnej, § 11).

Poza tym świadczeniodawca jest zobowiązany do umieszczenia wewnątrz budynków siedziby i jednostek organizacyjnych informacji dotyczących:

- imion i nazwisk osób kierujących pracą komórki organizacyjnej, a w przypadku ambulatoryjnej opieki zdrowotnej - także imion i nazwisk osób udzielających świadczeń oraz godzin i miejsca udzielania świadczeń;

- miejsc i godzin udzielania świadczeń przez podwykonawców, jeżeli zachodzi potrzeba poinformowania o tym świadczeniobiorców;

- zasad zapisów na porady i wizyty, z uwzględnieniem świadczeń udzielanych w warunkach domowych;

- trybu składania skarg i wniosków;

- praw pacjenta;

- adresu oraz numerów telefonów podmiotów udzielających świadczeń poza godzinami pracy określonymi w umowie, a w szczególności w dni wolne od pracy i w święta - w przypadku świadczeniodawców udzielających świadczeń podstawowej opieki zdrowotnej;

- numerów telefonów alarmowych ratownictwa medycznego, tj. numerów 112 i 999 ; 
- adresu oraz numeru telefonu właściwego miejscowo Rzecznika Praw Pacjenta oraz numeru bezpłatnej infolinii Biura Praw Pacjenta przy ministrze właściwym do spraw zdrowia;

- informacji o możliwości i sposobie zapisania się na listę oczekujących na świadczenie;

- innych informacji, jeżeli obowiązek ich ujawnienia świadczeniobiorcom wynika z umowy (http://www.zdrowie.abc.com.pl/czytaj/-/artykul/zakres-obowiazkupodawania-okreslonych-informacji-do-wiadomosci-pacjentow-przez-swiadczeniodawcow).

W przypadku świadczenia usług zdrowotnych w ramach Narodowego Funduszu Zdrowia wygląd tablic informacyjnych jest dokładnie określony. Informacje można pobrać ze stron Ministerstwa Zdrowia: „Wzór tablicy dla świadczeniodawcy udzielającego świadczeń opieki zdrowotnej w ramach umowy z NFZ". Podstawowe informacje o tablicy:

1) Wymiary tablicy: $600 \mathrm{~mm} \times 750 \mathrm{~mm}$.

2) Tło: białe.

3) Kolor elementów: PANTONE DS 184-1U (CMYK 100, 100, 0, 0).

4) Nazwa świadczeniodawcy: czcionka Arial bold 82 pkt, odległość między wierszami: 98,4 pkt.

5) Szczególne przypadki:

- Gdy wielu świadczeniodawców mających podpisaną umowę z Funduszem mieści się w jednym budynku, dopuszcza się możliwość umieszczania informacji o wszystkich zakładach opieki zdrowotnej w ramach jednej tablicy, pod jednym, wspólnym logo NFZ (poniżej paska). Dopuszcza się przy tym stosowanie skrótów, np. NZOZ Xyz w Krakowie.

- Gdy brak jest miejsca na zainstalowanie pełnowymiarowej tablicy, dopuszczalne jest zmniejszenie rozmiaru tablicy, pod warunkiem zachowania proporcji logo NFZ oraz czytelności tekstu, z zastrzeżeniem minimalnej szerokości tablicy np. $500 \mathrm{~mm}$ (ok. 17\% różnicy w stosunku do wymiaru podstawowego).

- Gdy świadczeniodawca udziela świadczeń w obiekcie zabytkowym, dopuszczalne jest wykonanie tablicy ze stali w kolorze srebrnym, pod warunkiem zachowania białego koloru tła dla logo NFZ (część tablicy ponad paskiem) (http://www.nfz.gov.pl/dla-swiadczeniodawcy/pliki-do-pobrania/identyfikacja/).

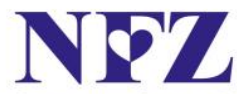

Narodowy Fundusz Zdrowia

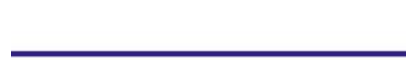

MIEJSCE NA WSTAWIENIE

NAZWY ŚWIADCZENIODAWCY

MIEJSCOWOŚCI

\section{Rysunek 1. Wzór tablicy dla świadczeniodawcy}

Źródło: http://www.nfz.gov.pl/dla-swiadczeniodawcy/pliki-do-pobrania/identyfikacja/ 
Zakłady lecznicze stoją więc przed szeregiem wyzwań związanych z promocją za pomocą klasycznych środków marketingowych. W związku z powyższym duży nacisk położony jest m.in. na element wizualizacyjny zarówno samego zakładu leczniczego - w szczególności nowo powstałego - oraz na prowadzenie coraz bardziej popularnych stron internetowych.

Od strony czysto estetycznej zakłady lecznicze mogą konkurować ze sobą zewnętrznymi atrybutami, jak elewacja budynków, wnętrza, logo. Nie bez znaczenia jest też dostępność do informacji, która często ma miejsce za pomocą stron własnych w Internecie lub - co rzadziej spotykane - prowadzonych blogów przez pracowników poszczególnych placówek, na których opisywane są najważniejsze wydarzenia z życia zakładu leczniczego.

\section{Elementy zewnętrznej wizualizacji zakładów leczniczych}

Pacjent, wybierając zakład leczniczy, często poza opinią o placówce lub nazwiskiem lekarza kieruje się wrażeniem, jakie wywiera na nim zakład. „Pacjenci mają coraz większe wymagania estetyczne i jak wykazują badania rynkowe - wrażenia wizualne mają obecnie zasadniczy wpływ na decyzje dotyczące wyboru placówki, w której zamierzają się leczyć. Estetyczna strona placówki jest bowiem namacalnym atrybutem jakości świadczonych usług" (Kapliński, Łysiak, Pięcińska (red.) 2001, cz. 10, rozdział 5, podrozdział 3, s. 4).

Zewnętrzna elewacja budynku powinna być estetyczna i dobrze oznakowana zgodnie z wymogami prawa. Wchodząc do zakładu leczniczego, pacjent/klient ocenia go przez pryzmat oświetlenia, koloru, temperatury, zapachu.

Wkraczając do gabinetu, pacjenci zastanawiają się nad tym (Mudie, Cottam 1998, s. 82):

- Jak wygląd zewnętrzny sygnalizuje to, co on ma do zaoferowania w środku?

- Jaką atmosferę kształtuje wnętrze?

- Jaki wywołuje nastrój/uczucia?

- Jakiego zachowania się ode mnie oczekuje?

Wizualne wskazówki umieszczone wewnątrz zakładu dają pacjentom/klientom poczucie bezpieczeństwa, profesjonalizmu i wysokiej jakości świadczonych usług. Za pomocą elementów wizualizacyjnych można także w placówce - szczególnie większej, z wieloma oddziałami - wydzielić poszczególne strefy:

- Publiczną, gdzie dochodzi do komunikacji między pacjentem a personelem.

- Leczniczą, gdzie ma miejsce kontakt pacjent-lekarz.

- Wewnętrzną, gdzie wstęp ma tylko personel

Link:

http://www.nowyszpital.pl/download/przetargi/2013-07/kolorystyka_oddzialow.pdf przedstawia propozycje wizualizacyjne rozwiązań kolorystycznych dla poszczególnych oddziałów w szpitalu. Ważne jest także, aby z pewnymi typami rozwiązań współgrało wyposażenie wnętrz. Dodatkowym elementem są zwyczajowo określone kolory dla wyposażenia zawierającego elementy ratujące życie, ppoż., materiały skażone biologicznie itp. 
W działaniach wizualizacyjnych wnętrz do ogólnego wizerunku zakładu leczniczego znaczącą rolę odgrywa kolorystyka (Bukowska-Piestrzyńska 2007, s. 93-97):

- Niskie oświetlenie połączone z ciepłą kolorystyką tworzy wnętrze przyjazne i intymne.

- Wysokie oświetlenie i kolory zimne to uczucie czystości i sterylności.

Przy wyborze kolorów ważne znaczenie odgrywa harmonia i wystrzeganie się „pstrokacizny”, tak aby przebywający w tych pomieszczeniach ludzie nie odczuwali z tego powodu zmęczenia.

W placówce mogą się także znajdować tablice informacyjne, których wygląd powinien współgrać z całą placówką. Poniżej, na Rysunku 2, ukazano inne możliwości budowania własnego wizerunku zakładu leczniczego za pomocą umieszczania logo/nazwy na plakatach reklamowych.

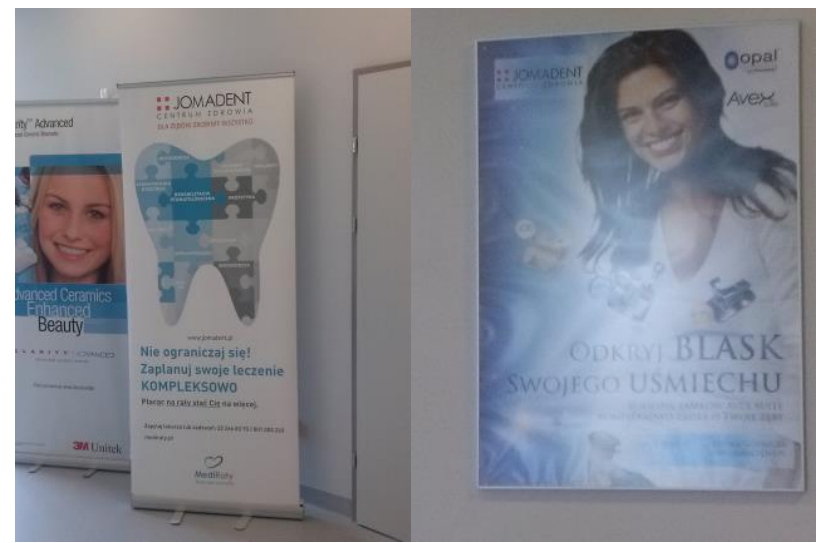

Rysunek 2. Przykładowe banery reklamowe z logo placówki leczniczej budowanie wizerunku placówki

Źródło: Opracowanie własne

Dobrze zaprojektowane logo, które pojawia się na tych plakatach dodatkowo informuje pacjentów/klientów o dbałości o wizerunek zakładu, a co za tym idzie - pozwala budować poczucie wysokiej jakości świadczonych w zakładzie usług. Tego typu rozwiązania znajdują się w wielu zakładach leczniczych i są ogólnie akceptowane.

\section{Strony internetowe jako możliwość promocyjna zakładów leczniczych}

Następnym aspektem promocji wizualizacyjnej zakładów leczniczych, który zostanie poruszony $\mathrm{w}$ tym artykule, jest wizualizacja za pomocą stron internetowych. Ich rozwój jest dynamiczny i większe zakłady lecznicze oferują szeroko rozbudowane strony internetowe $\mathrm{z}$ szeregiem informacji. Często posiadanie strony internetowej stanowi o „być albo nie być” w coraz bardziej zinformatyzowanym społeczeństwie. Z przeprowadzonego krótkiego wywiadu wynika, iż wśród 40 osób w przedziale wiekowym 30-50 lat 95\% korzysta ze stron internetowych zakładów leczniczych w celu zdobycia o nich podstawowych informacji. 
Z zastosowania Internetu mogą wyniknąć następujące korzyści (Bukowska-Piestrzyńska 2007, s. 114-115):

- możliwość poprawienia wizerunku placówki,

- udoskonalenie systemu obsługi pacjentów/klientów,

- poszukiwanie nowych kierunków rozwoju placówki,

- zwiększenie stopnia znajomości placówki i jej usług na rynku,

- redukcja kosztów.

Internet daje także możliwość interaktywnego kontaktu z odbiorcami. W przypadku zakładów leczniczych może być to możliwość rejestracji on-line czy też zadawania pytań skierowanych do lekarzy.

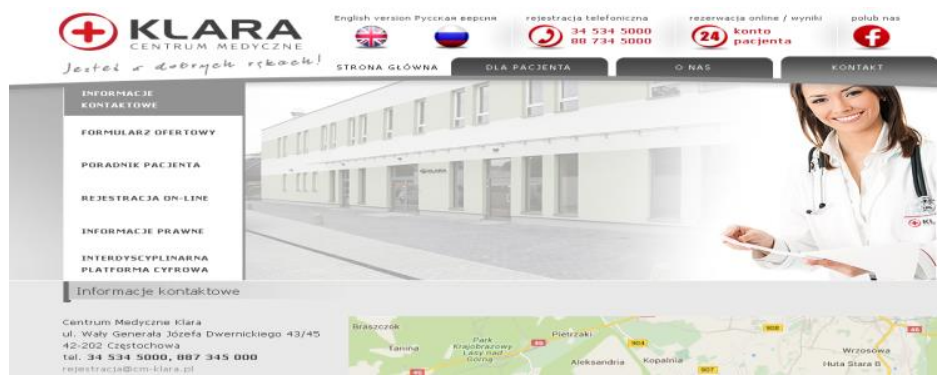

Rysunek 3. Przykład strony internetowej placówki leczniczej

Źródło: http://www.cm-klara.pl/kontakt/

Powyższy rysunek (Rysunek 3) może być tego przykładem. W zakładce Formularz ofertowy mamy możliwość zadawania pytań. Jest to również narzędzie do budowania bazy danych pacjentów lub potencjalnych pacjentów, gdyż do jego wypełnienia potrzebne są dane osoby zadającej pytanie. Istnieje także możliwość rejestracji on-line czy też pobrania wyników badań. Opcje te są bardzo wygodne i przyczyniają się do zwiększenia zadowolenia pacjentów, poprzez ułatwienie dostępu do danych, oszczędność czasu i dogodność.

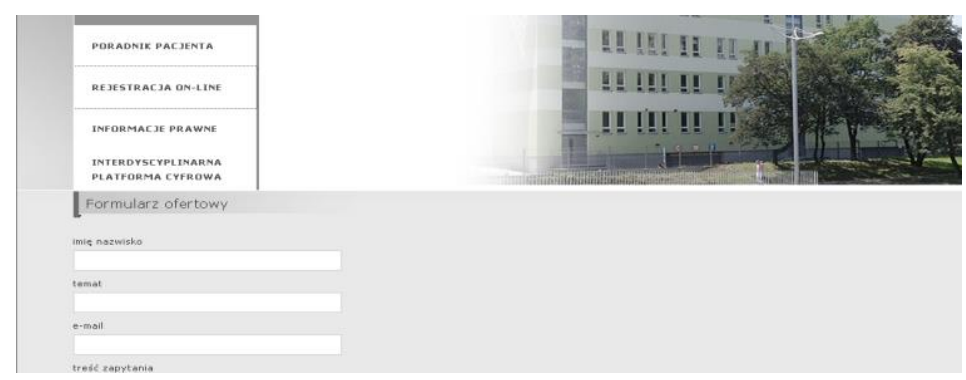

Rysunek 4. Przykładowy formularz ofertowy placówki leczniczej

Źródło: http://www.cm-klara.pl/kontakt/formularze-zapytan/

Przykładowa strona dostępu do danych on-line przedstawiona jest na Rysun$k u$ 5. Dostęp do danych jest chroniony hasłem oraz specjalnym rodzajem bezpiecznego połączenia. 


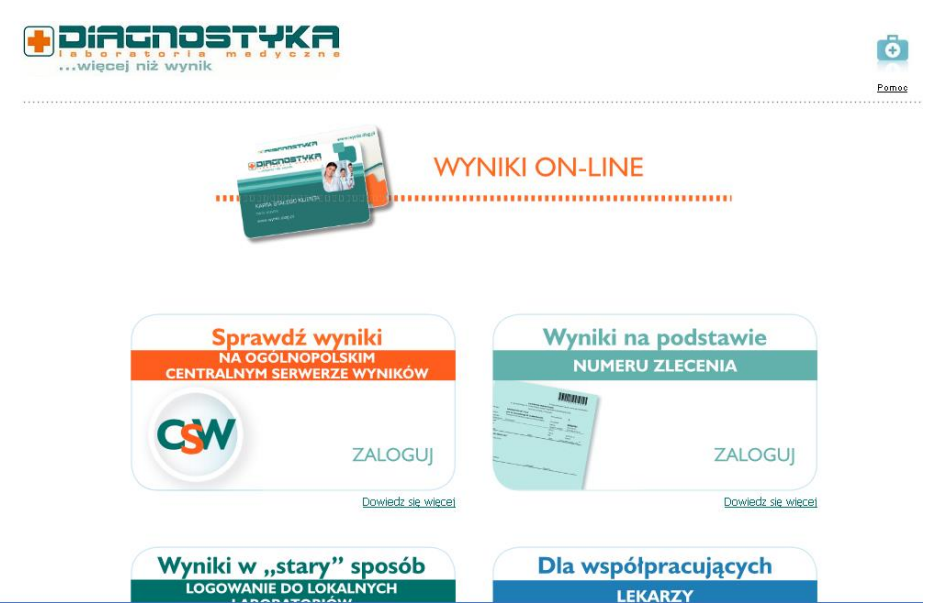

\section{Rysunek 5. Przykładowa strona dostępu do danych on-line}

Źródło: https://www.wyniki.diag.pl/

Na uwagę zasługuje fakt spójności graficznej powyższych stron internetowych przedstawionych na rysunkach. Kolorystyka stron nawiązuje do rozwiązań elewacyjnych reprezentowanych przez te strony zakładów leczniczych.

Największym wyzwaniem dla projektantów strony internetowej jest takie jej zaprojektowanie, aby była ona od pierwszego momentu atrakcyjna, spójna z ogólną wizją placówki oraz wyróżniająca się na tle innych. „Raport i Jaworski zaproponowali zastosowanie następujących siedmiu elementów projektowania, które nazwali 7C (Kotler, Shalowitz, Stevens 2013, s. 619):

- kontekst (context) - układ i projekt;

- zawartość (content) - tekst, grafika, dźwięk, filmy;

- społeczność (community) - umożliwianie komunikacji pomiędzy użytkownikami na stronie internetowej;

- indywidualizacja (customization) - możliwość dostosowania witryny do potrzeb indywidualnego użytkownika;

- komunikacja (communication) - komunikacja witryny z użytkownikiem, użytkownika $\mathrm{z}$ witryną lub komunikacja obustronna;

- połączenia (connection) - stopień połączenia witryny z innymi stronami;

- handel (commerce) - umożliwienie dokonywania zakupów na stronie.

Te elementy są cechami uniwersalnymi dotyczącymi tworzenia większości witryn internetowych. Dobrym rozwiązaniem podnoszącym oglądalność jest umieszczanie informacji o pozytywnych wydarzeniach, rozszerzeniu oferty o nowoczesne usługi itp. Jednakże najważniejszą cechą wydaje się być łatwość wykorzystania strony internetowej i jej przejrzystość. Łatwość wykorzystania to: możliwość szybkiego otwarcia strony, zrozumiałość i czytelność strony głównej, łatwość przełączania między szybko otwierającymi się stronami (Kotler, Shalowitz, Stevens 2013, s. 620). Z kolei zbytnie skomplikowanie strony i przeładowanie jej informacjami „na wejściu” może skutkować zniechęceniem użytkownika do skorzystania z serwisu. Przejrzystość strony pozwala podnieść jej atrakcyjność: pojedyncze 
strony wyglądają dobrze i nie są przeładowane zawartością, czcionki i ich rozmiary są czytelne, strona właściwie wykorzystuje grafikę i dźwięki (Kotler, Shalowitz, Stevens 2013, s. 620).

W świetle tych wskazówek można uznać, że przytoczone na powyższych rysunkach przykłady (wybrane w sposób przypadkowy) wydają się dobrze spełniać warunki i kryteria dobrej strony internetowej.

Podsumowaniem korzyści płynących z dobrze zaprojektowanej strony internetowej może być wypowiedź twórców publikacji pt. Zakład opieki zdrowotnej w praktyce: „Najważniejszym atutem przekazów internetowych jest ich interaktywność, czyli wrażenie osobistego kontaktu odbiorcy z nadawcą przekazu marketingowego [...]. Taki rodzaj komunikacji ma szczególne znaczenie właśnie w odniesieniu do witryn o charakterze medycznym, gdzie złudzenie bezpośredniej indywidualnej konsultacji jest decydującym czynnikiem pozyskiwania użytkowników - potencjalnych i realnych pacjentów" (Kapliński, Łysiak, Pięcińska (red.) 2001, cz. 10, rozdział 5, podrozdział 6.4, s. 22).

$\mathrm{Na}$ koniec, stosując narzędzie, jakim jest strona internetowa z możliwością interakcji, np. wystawiania komentarzy, należy zauważyć, że niestety zakład leczniczy musi liczyć się z możliwością otrzymania negatywnych, czasami krzywdzących opinii, które będą dostępne dla szerszego grona odbiorców. Daje to jednak możliwość wglądu w działania zakładu i szybkiego reagowania na pojawiający się kryzys.

\section{Podsumowanie}

W niniejszym artykule przedstawione zostały główne prawne założenia możliwości promocji zakładów leczniczych. Możliwości te, szczególnie dotyczące reklamy, są silnie ograniczone lub wręcz zakazane. Przytoczone akty prawne dosyć jasno to precyzują, nie wskazując równocześnie, co może być uznane stricte za reklamę, a co jest jedynie informacją. Jednocześnie zakład leczniczy chcący działać na coraz bardziej konkurencyjnym rynku polskim musi pozytywnie się wyróżniać na tle innych. Pomocne w tym mogą być, poza oczywiście usługami, dobre rozwiązania wizualizacyjnoinformacyjne, takie jak elewacja zewnętrzna budynku, logo, wnętrze i kolorystyka poszczególnych lokali, banery i plakaty informacyjne wewnątrz zakładu. Drugim przykładem możliwości promocyjnych zakładów leczniczych są właściwie zaprojektowane strony internetowe, za pomocą których można nawiązać kontakt z nowymi pacjentami oraz utrzymać starych. Przedstawione zasady i przykłady mogą stać się przyczynkiem do dokładniejszego przyjrzenia się tego typu rozwiązaniom.

\section{Literatura}

1. Bukowska-Piestrzyńska A. (2007), Marketing usług zdrowotnych. Od budowania wizerunku placówki do zadowolenia klientów, CeDeWu, Warszawa.

2. Czerw A. (red.) (2010), Marketing w ochronie zdrowia, Difin, Warszawa.

3. Dercz M., Rek T. (2007), Ustawa o zakładach opieki zdrowotnej. Komentarz, Wolters Kluwer, Warszawa.

4. Gubiński A. (1993), Komentarz do Kodeksu Etyki Lekarskiej, Zakład Informacyjno-Wydawniczo-Kolportażowy Okręgowej Izby Lekarskiej w Warszawie, Warszawa.

5. http://www.cm-klara.pl/kontakt/ (dostęp: 01.10.2015). 
6. http://www.cm-klara.pl/kontakt/formularze-zapytan/ (dostęp: 01.10.2015).

7. http://www.nfz.gov.pl/dla-swiadczeniodawcy/pliki-do-pobrania/identyfikacja/ (17.09.2015).

8. http://www.nowyszpital.pl/download/przetargi/2013-07/kolorystyka_oddzialow.pdf (dostęp: 29.09.2015)

9. http://www.prawoimedycyna.pl/?str=artykul\&id=1023 (dostęp: 14.09.2015).

10. http://www.zdrowie.abc.com.pl/czytaj/-/artykul/nowe-definicje-i-podmioty-przewodnik-poustawie-z-dnia-15-kwietnia-2011-r-o-dzialalnosci-leczniczej (dostęp: 11.09.2015).

11. http://www.zdrowie.abc.com.pl/czytaj/-/artykul/zakres-obowiazku-podawania-okreslonychinformacji-do-wiadomosci-pacjentow-przez-swiadczeniodawcow (dostęp: 16.09.2015).

12. https://www.wyniki.diag.pl/ (dostęp: 01.10.2015).

13. Janiszewska K., Korsak R., Kwarciak B., Lewiński P., Lisowska-Magdziarz M., Nierenberg B., Nowińska E., Zimny R. (2009), Wiedza o reklamie. Od pomysłu do efektu, Wydawnictwo Szkolne PWN, Warszawa-Bielsko-Biała.

14. Kapliński K., Łysiak M.R., Pięcińska T.S. (red.) (2001), Zakład opieki zdrowotnej w praktyce, Verlag Dashofer, Warszawa.

15. Kodeks Etyki Lekarskiej - uchwała Nadzwyczajnego II Krajowego Zjazdu Lekarzy z dnia 14 grudnia $1991 \mathrm{r}$. z późn. zm.

16. Kotler Ph., Shalowitz J., Stevens R.J. (2013), Marketing strategiczny w opiece zdrowotnej, Wolters Kluwer, Warszawa.

17. Mudie P., Cottam A. (1998), Usługi. Zarządzanie i marketing, Wydawnictwo Naukowe PWN, Warszawa.

18. Rozporządzenie Ministra Zdrowia z dnia 6 maja 2008 r. w sprawie ogólnych warunków umów o udzielanie świadczeń opieki zdrowotnej (Dz.U. 2008 nr 81 poz. 484, z późn. zm.).

19. Ustawa z dnia 15 kwietnia 2011 r. o działalności leczniczej (Dz.U. nr 112 poz. 654).

20. Ustawa z dnia 2 grudnia 2009 r. o izbach lekarskich (Dz.U. z 2009 nr 219 poz. 1708, z późn. zm.).

21. Ustawa z dnia 29 grudnia 1992 r. o radiofonii i telewizji (Dz.U. $2011 \mathrm{nr} 43$ poz. 226, z późn. zm.).

22. Ustawa z dnia 30 sierpnia 1991 r. o zakładach opieki zdrowotnej (Dz.U. 1991 nr 91 poz. 408).

\title{
ACTION OF VISUALIZATION IN SELECTED HEALTH CARE ORGANIZATIONS AS A MANIFESTATION POSSIBILITY OF PROMOTION IN THE HEALTH CARE SECTOR
}

\begin{abstract}
This article presents the main assumptions of the promotion for the health care organizations. The emphasis is on page promotion by visualization. They presented the possibilities and limitations in this regard, as well as legislation and good practice, which regulates promotion opportunities and in particular advertising plants medical article focuses mainly on the elements relating to external information located on the clinics indicating good solutions as well as shortcomings in this regard. The second aspect concerns created websites and their impact on better identification of a specific plant. The aim of the article is critical to look at the challenges faced by marketing management in the clinics and promotion opportunities for visualization of these. The article is based on studies of their own, both for observing individual plants medicinal solutions, and direct interview with patients and potential patients certain establishments. The study concerns recognition websites like concrete organizations. The article can be a hint for managing health care organizations how to use these tools for better management of the facility, which should be paid attention to, what are the limitations of where to look for solutions, what mistakes and imperfections avoided and, in particular, as these measures perceive customers health care organizations or patients.
\end{abstract}

Keywords: promotion, health care organizations, visualization, constraints, challenges, websites 